\title{
PERAN PENGEMBANGAN TEKNOLOGI PENDIDIKAN DALAM MENINGKATKAN KUALITAS PEMBELAJARAN
}

\author{
Anindya Ika Yulia ${ }^{1}$, Hastuti Diah Ikawati ${ }^{2}$ \\ ${ }^{1,2}$ Fakultas Ilmu Pendidikan Dan Psikologi Undikma \\ Email: hastutidiahikawati@gmail.com
}

\begin{abstract}
Abstrak
Tujuan penulisan artikel adalah untuk memberikan gambaran dalam pembelajaran menggunakan teknologi pendidikan yang semakin maju pada saat ini. Tetapi tidak lupa pula untuk membaca dan menulis, karena itu sebuah kewajiban bagi guru untuk mengembangkan wawasan dan mengembangkan potensi diri agar mampu mengajar anak didik dengan lebih baik. Terlebih kini guru juga dituntut untuk tidak ketinggalan perkembangan teknologi. Perkembangan teknologi yang semakin canggih menjadi sarana penting untuk mencapai tujuan pendidikan yang lebih efektif dan efesien. Namun di balik itu menjadi tuntutan besar bagi para dosen/guru untuk mengembangkan kemampuan dalam menguasai teknologi dan media pembelajaran. Dengan melihat konsepsi dasar Teknologi Pendidikan dan perkembangan lapangan kerja saat ini, maka akan banyak profesi - profesi Teknologi Pendidikan baru yang akan muncul baik di Indonesia atau luar negeri.

Katakunci: perananan dan fungsi, pengembang teknologi pendidikan, kualitas pembelajaran
\end{abstract}

\section{INTRODUCTION}

Teknologi pendidikan perlu dipikirkan dan dibahas terus menerus karena adanya kebutuhan riil yang mendukung pertumbuhan dan perkembangannya yaitu ( i) Tekad untuk mengadakan perluasan dan pemerataan kesempatan belajar, Keharusan meningkatkan mutu pendidikan antara lain, penyempurnaan kurikulum, (ii) penyediaan berbagai sarana pendidikan, dan peningkatan kemampuan tenaga pengajar lewat berbagai bentuk pendidikan serta latihan, ( iii ) Penyempurnaan sistem pendidikan dengan penelitian dan pengembangan sesuai dengan tantangan jaman dan kebutuhan pembangunan, (iv) Peningkatan partisipasi masyarakat dengan pengembangan dan pemanfaatan berbagai wadah dan sumber pendidikan, (v) Penyempurnaan pelaksanaan interaksi antara pendidikan dan pembangunan di mana manusia dijadikan pusat perhatian pendidikan. Rooijakkers (1991:189-228) dalam bukunya yang bertajuk Mengajar dengan Sukses memberi petunjuk kepada seorang guru yang ingin mengajar dengan sukses, yang salah satu adalah keterampilan guru dalam membuat karya ilmiah atau tulisan lain yang bertujuan untuk mempermudah terjadinya proses belajar di pihak siswa. Guru tidak cukup hanya berbicara di muka kelas saja tetapi usaha itu perlu dibarengi dengan berkomunikasi lewat media seperti misalnya modul, diktat, makalah atau tulisan ilmiah.

Teknologi Pendidikan di Indonesia telah memiliki ikatan profesi resmi yaitu Ikatan Profesi Teknologi Pendidikan Indonesia (IPTPI). IPTPI bertujuan menghimpun sumber daya untuk menyumbangkan tenaga dan pikiran bagi pengembangan Teknologi Pendidikan sebagai suatu teori, bidang, dan profesi di tanah air, bagi pemanfaatan kemajuan warga dan bangsa Indonesia.

\section{LITERATURE VIEW}

Abdul L. Zachri (Miarso; 2004) menyatakan penerapan ilmu Teknologi Pendidikan di Indonesia sudah dimulai sejak tahun 1970 hingga sampai saat ini, banyak implementasi dari keilmuan Teknologi Pendidikan yang sudah diadaptasi dan digunakan dalam sistem pendidikan Indonesia seperti (1) pembelajaran dengan teknologi dengan modul, (2) Pustekkom, (3) SMP Terbuka, (4) Universitas Terbuka, dan (5) Pendidikan keahlian Teknologi Pendidikan pada jenjang sarjana, pascasarjana. Namun masyarakat umum belum mengetahui peran teknologi pendidikan dibalik itu 
semua. Dalam menggunakan teknologi kita pun tidak jauh dari media apa yang akan kita pakai, Media adalah sebuah alat yang mempunyai fungsi menyampaikan pesan (Bovee, 1997). Masuknya komputer dalam proses belajar, menurut Andi Hakim, melahirkan suasana yang menyenangkan karena peserta didik dapat mengendalikan kecepatan belajar sesuai dengan kemampuannya. Lalu gambar dan suara yang muncul membuat anak tidak cepat bosan, sebaliknya justru merangsang untuk mengetahui lebih jauh lagi. Media mengandung pesan sebagai perangsang belajar dan dapat menumbuhkan motivasi belajar sehingga siswa tidak menjadi bosan dalam meraih tujuan-tujuan belajar (Putra Sumberharjo, dkk, 2015)

Yusufhadi Miarso mendeskripsikan kompetensi Teknologi Pendidikan dapat dilakukan dengan menggunakan dua pendekatan. Pendekatan pertama adalah dengan bertolak dari kebutuhan nyata yang sudah ada, dan pendekatan kedua bertolak dari analisis teoritik dan empirik. Meskipun memakai dua buah pendekatan, seharusnya penjabaran kompetensi akan sama.

Pertama, pendekatan kebutuhan. Melalui pendekatan kebutuhan kita dapat mengetahui ilustrasi kompetensi profesi Teknologi Pendidikan dari rincian pekerjaan yang dilakukan oleh para lulusan Teknologi Pendidikan di lapangan pekerjaan. Berdasarkan hasil tracer study yang dilakukan secara berkala oleh Pogram Studi Teknologi Pendidikan UNJ pada tahun 2014 hingga 2016, kompetensi Teknologi Pendidikan selalu berkembang. Kedua, Teknologi Pendidikan melalui pendekatan teoritis, yaitu pendekatan ini dilakukan dengan menganalisis definisi Teknologi Pendidikan itu sendiri.

Teknologi Pendidikan adalah proses kompleks yang terintegrasi meliputi : orang, prosedur, gagasan, sarana dan organisasi untuk menganalisis masalah dan merancang, melaksanakan, menilai dan mengelola pemecahan masalah dalam segala aspek belajar pada manusia. (AECT, 1977). Khoe Yao Tung (2000) mengatakan bahwa setelah kehadiran dosen dalam arti sebenarnya, internet akan menjadi suplemen dan komplemen dalam menjadikan wakil guru yang mewakili sumber belajar yang penting di dunia. Menurut PP No. 38 tahun 1992 pasal 61 (Syaefudin Saud, 2010: 129) menyebutkan bahwa tenaga kependidikan dapat membentuk ikatan profesi sebagai wadah untuk meningkatkan atau mengembangkan karier, kemampuan, kewenangan profesional, martabat, dan kesejahteraan tenaga kependidikan.

Keberadaan teknologi harus dimaknai sebagai upaya untuk meningkatkan efektivitas dan efisiensi dan teknologi tidak dapat dipisahkan dari masalah, sebab teknologi lahir dan dikembangkan untuk memecahkan permasalahan yang dihadapi oleh manusia. Berkaitan dengan hal tersebut, maka teknologi pendidikan juga dapat dipandang sebagai suatu produk dan proses (Sadiman, 1993).

Adapun Manfaat penggunaan internet, khususnya dalam pendidikan terbuka dan jarak jauh (Elangoan, 1999; Soekartawi, 2002; Mulvihil, 1997; Utarini, 1997), antara lain; Pertama, Tersedianya fasilitas e-moderating di mana dosen dan mahasiswa dapat berkomunikasi secara mudah melalui fasilitas internet secara regular atau kapan saja kegiatan berkomunikasi itu dilakukan dengan tanpa dibatasi oleh jarak, tempat dan waktu. Kedua, Dosen dan mahasiswa dapat menggunakan bahan ajar atau petunjuk belajar yang terstruktur dan terjadwal melalui internet, sehingga keduanya bisa saling menilai sampai berapa jauh bahan ajar dipelajari. Ketiga, Mahasiswa dapat belajar atau me-review bahan ajar (mata kuliaha) setiap saat dan di mana saja kalau diperlukan mengingat bahan ajar tersimpan di komputer. Keempat, Bila mahasiswa memerlukan tambahan informasi yang berkaitan dengan bahan yang dipelajarinya, ia 
dapat melakukan akses di internet secara lebih mudah. Kelima, Baik dosen maupun mahasiswa dapat melakukan diskusi melalui internet yang dapat diikuti dengan jumlah peserta yang banyak, sehingga menambah ilmu pengetahuan dan wawasan yang lebih luas. Keenam, Berubahnya peran mahasiswa dari yang biasanya pasif menjadi aktif. Ketujuh, Relatif lebih efisien. Misalnya bagi mereka yang tinggal jauh dari perguruan tinggi atau sekolah konvensional.

\section{CONCLUSION}

Dengan membaca referensi tentang Teknologi Pendidikan dan juga pengembangan nya, dapat dilihat dengan perkembangan zaman/teknologi/budaya, maka masih akan banyak profesi-profesi Teknologi Pendidikan baru yang akan muncul baik di Indonesia atau luar negeri dan lapangan pekerjaan pun akan segera menggunakan para alumni sebagai profesi di instansinya. Sebuah profesi, keilmuan Teknologi Pendidikan harus dapat mengantisipasinya dalam sebuah ketentuan yang lebih sistematis dan sistemik, sehingga dapat menaungi para profesi dalam bidang Teknologi Pendidikan. Oleh karena itu para pendidik harus terus belajar mengenai perkembangan teknologi sehingga pembelajaran bisa terlaksana dengan baik, tetapi tidak hanya pendidik yang harus terus belajar tapi peserta didik juga harus belajar mengenai perkembangan teknologi dikarenakan zaman sekarang sudah canggih sehingga peserta didik bisa mendapatkan pengetahuan yang lebih luas.

\section{REFERENCE}

Ariani Diana. 2017. Aktualisasi Profesi Teknologi Pendidikan di Indonesia. Indonesian Journal of Curriculum and Educational Technology Studies 5 (1) (2017):

Gusniati. 2017. Peningkatan Kompetensi Profesional Guru Dalam Menyusun Laporan Penelitian Tindakan Kelas Melalui Model Pembinaan Clck (Contoh, Latihan, Control, Kerja Mandiri) Berbasis Mentoring Di Sdn 22 Sungai Limau. JURNAL MANAJEMEN PENDIDIKAN No.02 Vol.02 th.2017

Ikatan Profesi Teknologi Pendidikan Indonesia. (2016). Tentang IPTPI. Diunduh dari www. Iptpi.org/

Hafiar, H., Damayanti, T., Subekti, P. dan Fatma, D. 2015. Peningkatan Pendidikan Dan Pengembangan Kompetensi Guru Sma Negeri 1 Katapang Melalui Partisipasi Dalam Publikasi Akademis Di Media Massa. Dharmakarya: Jurnal Aplikasi Ipteks untuk Masyarakat . ISSN 1410 - 5675 . Vol. 4, No. 2, Nopember 2015: 88 - 92

Hadi, Ananda Elyas. 2018. Penggunaan Model Pembelajaran E-Learning Dalam Meningkatkan Kualitas Pembelajaran. Jurnal Warta Edisi : 56. ISSN : 1829 7463

Meri, Rogantina Andri. 2017. Peran Dan Fungsi Teknologi Dalam Peningkatan Kualitas Pembelajaran. Jurnal Ilmiah Research Sains VOL. 3. NO. 1 Februari

Suryadi, Sudi. Peranan Perkembangan Teknologi Informasi Dan Komunikasi Dalam Kegiatan Pembelajaran Dan Perkembangan Dunia Pendidikan. Informatika : Jurnal Ilmiah AMIK Labuhan Batu Vol.3 No.3 /September/2015 9

Zuzandi. 2019. Pembangan Profesi Dan Karir Guru. Manajer Pendidikan, 2019 ejournal.unib.ac.id

Retnoningsih, Endang. 2019. Peran Dan Fungsi Media Komputer Dalam Pembelajaran Di Sekolah 
Jurnal Cahaya Mandalika, Vol. 2, No. 3, November 2021 ,e- ISSN: 2721-4796

Available online at: http://ojs.cahayamandalika.com/index.php/JCM

Copyright @ 2021 Publisher: Institut Penelitian \& Pengembangan Mandalika Indonesia

Tafonao, Talizaro . 2018. Peranan Media Pembelajaran Dalam Meningkatkan Minat Belajar Mahasiswa. Jurnal Komunikasi Pendidikan, Vol.2 No.2, Juli 2018 P-ISSN 25491725 E-ISSN 2549-4163 103 - Jurnal Komunikasi Pendidikan, journal.univetbantara.ac.id 